Analysis of fine particulates from fuel burning in a reconstructed building at Neolithic Çatalhöyük, Turkey and implications for respiratory health in early settled communities

Lisa-Marie Shillito ${ }^{1}$

Anil Namdeo ${ }^{2}$

Aishwarya Vikram Bapat ${ }^{3}$

Helen Mackay ${ }^{4}$

Scott D. Haddow 5

1. School of History, Classics and Archaeology, Newcastle University, UK lisamarie.shillito@ncl.ac.uk https://orcid.org/0000-0002-6176-531X (corresponding author)

2. Department of Geography and Environmental Sciences, Northumbria University, UK https://orcid.org/0000-0002-0982-9590

3. School of Engineering, Newcastle University, UK

4. Department of Geography, Durham University, UK https://orcid.org/0000-0002-8705-8330

5. Department of Cross-Cultural and Regional Studies, Copenhagen University, Denmark https://orcid.org/0000-0002-3970-7447 


\title{
Analysis of fine particulates from fuel burning in a reconstructed building at Neolithic Çatalhöyük, Turkey and implications for respiratory health in early settled communities
}

\begin{abstract}
The use of wood, dung and other biomass fuels can be traced back to early prehistory. Whilst the study of prehistoric fuel use and its environmental impacts is well established, there has been little investigation of the health impacts this would have had, particularly in the Neolithic period, when people went from living in relatively small groups, to living in dense settlements. The UNESCO World Heritage Site of Çatalhöyük, Turkey, is one of the earliest large 'pre-urban' settlements in the world. In 2017 a series of experiments were conducted to measure fine particulate ( $\left.\mathrm{PM}_{2.5}\right)$ emissions during typical fuel burning activities, using wood and dung fuel. The results indicate that both fuels surpassed the WHO and EU standard limits for indoor air quality, with dung fuel being the highest contributor for $\mathrm{PM}_{2.5}$ pollution inside the house, producing maximum values $>150,000 \mu \mathrm{g} \mathrm{m}^{-3}$. Maximum levels from wood burning were $36,000 \mu \mathrm{g} \mathrm{m}^{-3}$. Average values over a 2-3 hour period were $13-60,000 \mu \mathrm{g} \mathrm{m}^{-3}$ for dung and $10-45,000 \mu \mathrm{g} \mathrm{m}^{-3}$ for wood. The structure of the house, lack of ventilation and design of the oven and hearth influenced the air quality inside the house. These observations have implications for understanding the relationship between health and the built environment in the past.
\end{abstract}

\section{Keywords:}

Çatalhöyük, air quality monitoring, biofuel, $\mathrm{PM}_{2.5}$ pollution.

\section{Introduction}

Air pollution is often associated with industrialisation in the $19^{\text {th }}$ century, but the origins of anthropogenic air pollution can be seen much earlier. The earliest evidence for exposure to pollutants is seen in Neanderthals at the Spanish cave site of El Sidron where chemical signals in teeth show smoke inhalation from campfires around 49,000 years ago (Hardy et al. 2012). Early hominid populations were the first to manipulate fire for warmth and cooking (Berna et al. 2012), an ability that accelerated with permanent settlement and the development of pyrotechnologies. The development of pottery production, followed by early metal working and eventually for more sophisticated processes such as glass making, all involved the use of fuels, increasing people's exposure to by-products of smoke and other pollutants.

Çatalhöyük is a UNESCO World Heritage Site, and is an ideal case study for investigating relationships between health and the built environment in prehistory. The site has $>1000$ years of continuous occupation from the pre-pottery Neolithic to Chalcolithic period 7100 - 5700 BC (Hodder 2006, Bayliss et al. 2015). At its peak, over 8000 people lived there. Each level of occupation at Çatalhöyük contains multiple mudbrick buildings ranging in size from 15 to $25 \mathrm{~m}^{2}$, clustered into 'neighbourhoods'. Large open areas between neighbourhood clusters contain substantial build up of midden deposits and 'bonfire' deposits (Shillito et al. 2011). A typical building has a central room with and oven and hearth, and slightly elevated platforms (Figure 1). The interior of these rooms, including the platforms, are coated with white plaster, and microscopic observations have shown layer of soot and frequent re-plastering (Matthews 2005). The buildings are estimated to have been in use for 70 years before being dismantled and rebuilt in the same location. These processes of rebuilding occur multiple times over the site's occupation (Cessford 2005; Düring 2005). The Çatalhöyük settlement changes from a dense agglomeration in its earliest phase, where individual buildings are constructed wall to wall with no gaps or streets between them, to a more open nucleated settlement towards the end of the occupation. 

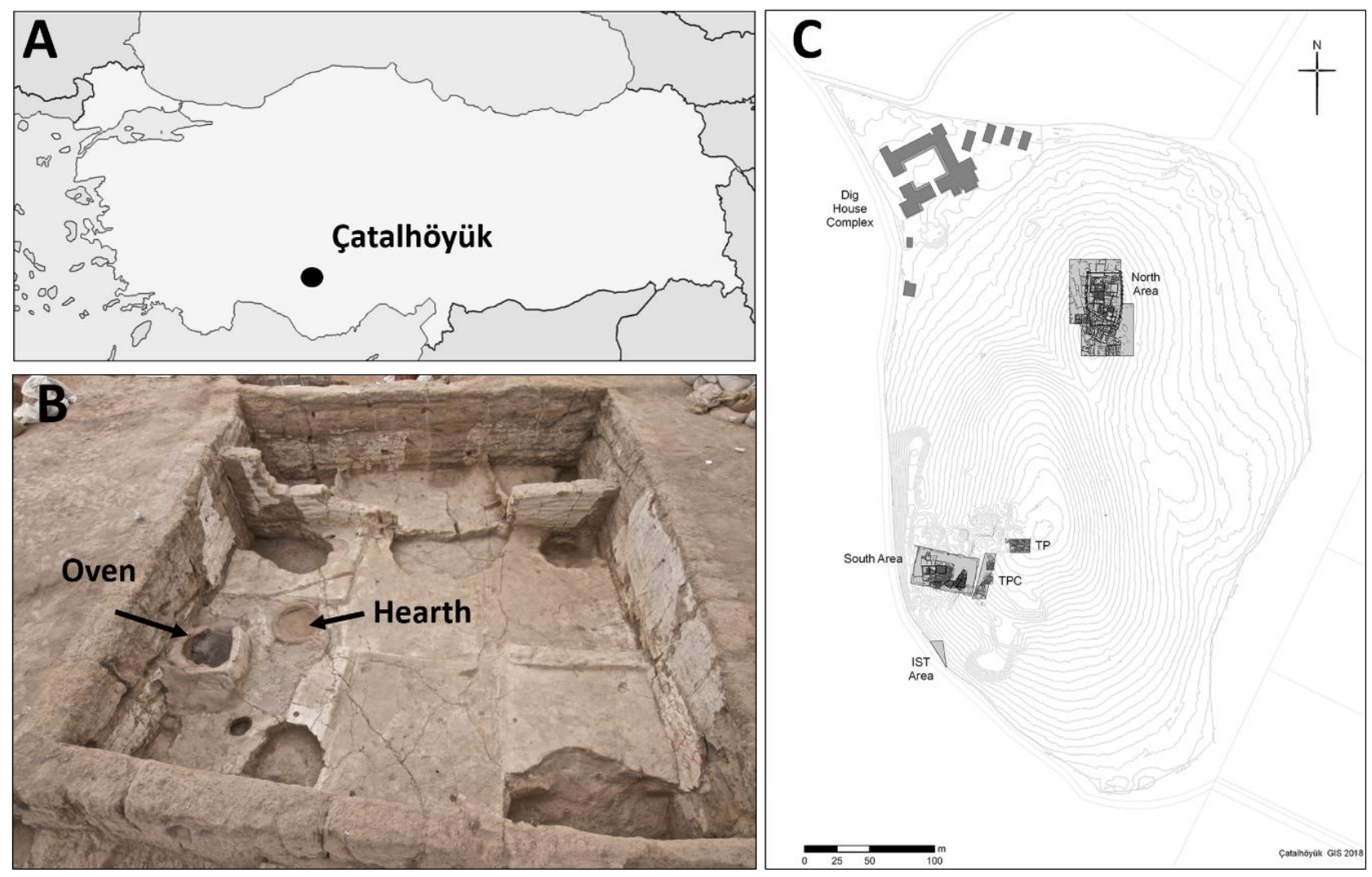

Figure 1: A. Map showing the location of Çatalhöyük in Turkey. Outline map from Wikimedia commons. B. Building 119 in North Area, excavated 2014, showing a typical example of an oven and hearth. Photo courtesy of Çatalhöyük project CC BY-NC-SA 2.0. C. Plan of the site showing excavation areas. Plan by Camilla Mazucatto.

A wide range of materials have been used as fuels in prehistory including animal dung, reeds, peat/turf and agricultural waste products (Braadbaart et al. 2017). In some cases non-wood fuels were preferentially selected for particular activities e.g. dung for pottery production, as it burns more evenly and slowly than wood (Sillar 2000). Research at Çatalhöyük and other sites in Anatolia suggests that non-wood fuels, particularly Phragmites reeds and animal dung, became more important over time (Shillito et al. 2011, Portillo et al. 2020). There is also evidence that certain fuel-burning activities were located outdoors (Bogaard et al 2014, Shillito and Ryan 2013), and that dung is associated more with outdoor burning activities (Portillo et al. 2020). Given the large volume of fuel by-product deposits and the ubiquity of fuel burning activities, it is highly likely that the inhabitants were exposed to air pollutants from burning. High concentrations of silica particles in the form of phytoliths from grasses and reeds have also been identified in fuel deposits (Shillito et al. 2011, Portillo et al. 2020), which are known in historic and modern contexts to cause silicosis, a lung disease caused by inhalation of silica dust (Köksal and Kahraman. 2011, Akgün et al. 2013).

We know from modern studies that burning 'biofuels' has significant negative consequences on health, especially in enclosed spaces with poor ventilation, but the relationship between fuel use and health in prehistory has never been explored. Studies of health in the archaeological record are typically focused on the analysis of human skeletal remains. There are several indicators of respiratory disease that can be detected in the osteoarchaeological record, for example inflammation of the maxillary sinuses, and lesions on the visceral surfaces of ribs, which can be linked to diseases such as tuberculosis, chronic bronchitis, pneumonia and cancer (Roberts 2015, Roberts 2007, Binder and Roberts 2014, Davies-Barrett et al. 2019). Whilst there are some examples of Neolithic populations with skeletal indicators of respiratory disease (Sparacello et al. 2016, Sparacello et al. 
2017), respiratory diseases do not always leave such traces on bone. Complicating our interpretation further is the so-called "osteological paradox" (Wood et al. 1992) in which a skeleton with a "healthy" appearance (i.e. free of bony lesions) may indicate an individual who succumbed very quickly to disease before their bones could be affected. Alternatively, individuals with significant skeletal indicators of disease are likely to have lived with their illnesses for an extended period before succumbing.

Recent advances in emission and dispersion modelling in urban environment, coupled with the availability of details time activity patterns and pervasive monitoring of air pollution in our cities can enhance our understanding of individual and community level exposures and disease burdens (Namdeo et al. 2011, Namdeo et al. 2015). The exceptional preservation of buildings at Çatalhöyük means that there is much potential for applying these modern methodologies to this prehistoric settlement, and to provide estimations of exposure levels that could help better understand the links between the built environment and health in the past. This may provide an alternate line of evidence that can be assessed alongside osteoarchaeological data.

Between 1997 - 1999 a replica of a Neolithic mudbrick building at Çatalhöyük was constructed to the south of the site's visitor centre, to provide a visual representation of what one of the houses may have looked like during the time of occupation (Gargett 2017). A team of archaeologists and local builders from the local village of Küçükköy and Çumra made mudbricks using traditional materials and used these to replicate a 'typical' building, as seen in the archaeological record (Stevanović 1999). Hay was used for a thatched roof and the inside was plastered. The entrance of the house was typically from the roof of the structure, with no windows or doorways (the modern replica has a doorway for practical purposes). Experimental archaeology and replicas of archaeological buildings have been used at several sites as an educational tool for visitors, and these reconstructions are also increasingly used for research purposes (e.g. Rhyl-Svensen et al. 2010, Banerjea et al. 2015). The aim of this research was to measure pollution levels from episodes of fuel use to test how living in these buildings may have impacted the exposure of the inhabitants to fine particulate matter and thus their respiratory health. The focus of the study is $\mathrm{PM}_{2.5}$, fine particulate matter with a diameter of 2.5 microns or less. These particles are the most serious health risk in air pollution, as they are small enough to travel deep into the lungs, where they become embedded.

\section{Methodology}

\subsection{Experimental set up}

The experiments were conducted over three days, $11^{\text {th }}, 12^{\text {th }}$ and $13^{\text {th }}$ of July 2017 . During this period the regional temperature averaged $24^{\circ} \mathrm{C}$ with no precipitation and calm winds (Merra SoDa, 2019). Five tests were conducted to measure the $\mathrm{PM}_{2.5}$ emissions under two different set-ups (Table 1, Figure 2). Test 1 was set up to assess background dust levels. Set Up 'A' (tests, 3, 4 and 5) was designed to measure the $\mathrm{PM}_{2.5}$ levels released from the oven, while set up 'B' (test 2) was designed to measure the $\mathrm{PM}_{2.5}$ levels due to burning of fuel in the hearth.

The oven was enclosed from three sides with an opening at the front to load where fuel is loaded, and another smaller opening at the top to release the smoke produced. The hearth area to the front of the oven was completely open on all sides. Two types of biofuel were selected, wood and dung. The fire was built with the help of local residents from Küçükköy, who supplied the dung and wood. The grass-fed cow dung used in the tests was dried prior to the investigation. 

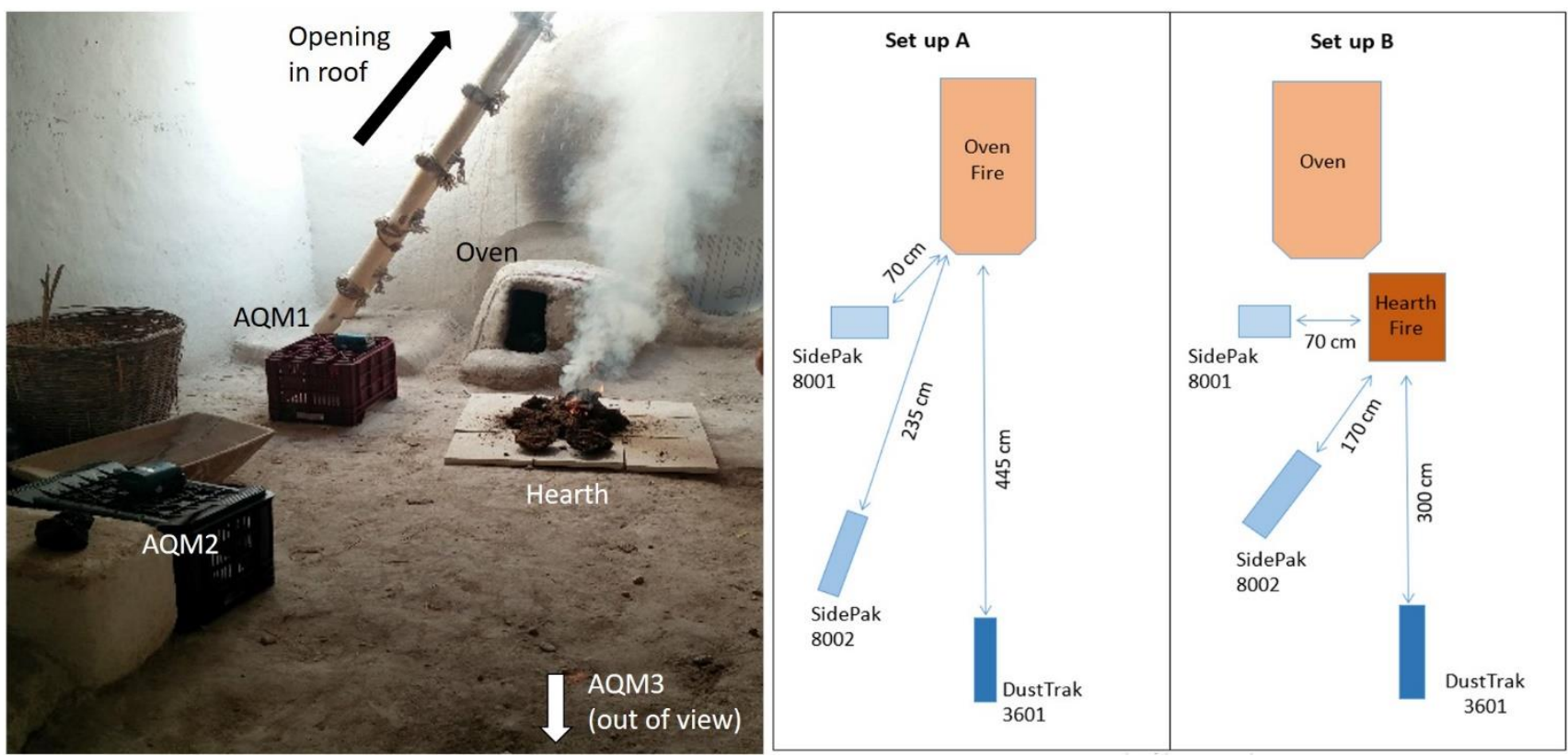

Figure 2: plan of the Set-up A (fuel in oven) and Set up B (fuel on hearth area)

Table 1: Details of the tests conducted

\begin{tabular}{|c|c|c|c|c|c|}
\hline Test & $\begin{array}{l}\text { Set } \\
\text { Up }\end{array}$ & Duration (mins) & Fuels used & $\begin{array}{l}\text { Fuel } \\
\text { location }\end{array}$ & Purpose \\
\hline 1 & - & 15 & None & - & $\begin{array}{l}\text { Background dust } \\
\text { measurements }\end{array}$ \\
\hline 2 & $\mathrm{~B}$ & 240 & Dung & Hearth & Dung fuel test \\
\hline 3 & $\mathrm{~A}$ & 156 & Wood & Oven & Wood fuel test \\
\hline 4 & $\mathrm{~A}$ & 280 & Wood and Dung & Oven & Mixed fuel test \\
\hline 5 & $\mathrm{~A}$ & 628 & Wood and Twigs & Oven & $\begin{array}{l}\text { Wood fuel test - extended } \\
\text { duration }\end{array}$ \\
\hline
\end{tabular}

\subsection{Fine particulate measurements and data analysis}

Three Air Quality Monitoring (AQM) stations were used for the measurement the air pollution inside the house, one TSI SidePak AM510 Personal Aerosol Monitor, one TSI SidePak AM520 and one TSI DustTrak 2601 monitor (Table 2). These were set up to monitor PM 2.5 concentration and calibrated to zero before the experiments.

Table 2: Air Quality Monitoring (AQM) stations used in this study

\begin{tabular}{|l|l|l|l|}
\hline Air Quality Monitoring station & $\begin{array}{l}\text { Aerosol concentration } \\
\text { range }\left(\mathrm{mg} / \mathrm{m}^{3)}\right.\end{array}$ & $\begin{array}{l}\text { Particle } \\
\text { size }(\mu \mathrm{m})\end{array}$ & $\begin{array}{l}\text { Abbreviation } \\
\text { used }\end{array}$ \\
\hline SidePak8001 (AM510) & 0.001 to 20 & 0.1 to 10 & AQM1 \\
\hline SidePak8002 (AM520) & 0.001 to 20 & 0.1 to 10 & AQM2 \\
\hline DustTrak3601 & 0.001 to 150 & 0.1 to 15 & AQM3 \\
\hline
\end{tabular}


The average and maximum values, and standard deviations, were compared between setups (Table 3 ). Comparisons between the AQMs was limited in some cases due to the emissions exceeding the capacity of the monitors. AQM1 and AQM2 have a lower capacity than AQM3 and were exceeded at multiple points. In test 2 where dung was burnt on the hearth, all three monitors were exceeded. Due to the maximum capacity of AQM1 and AQM2 being exceeded in some of the tests, the missing entries for these data points was replaced with the highest limit of the machines (20000), prior to statistical analysis. As the AQMs ran for different lengths of time in each experiment, the period of comparison was set at 2 hours 36 minutes for all experiments, to avoid for example misleading averages caused by an AQM continuing to collect data beyond the duration of the burning period.

\section{Results}

In test 1 the background levels of PM ${ }_{2.5}$ in the building were recorded for 15 minutes for each AQM (Table 3, Figure 3). The values ranged from 16-585 $\mu \mathrm{g} \mathrm{m}^{-3}$ and averaged 62-112 $\mu \mathrm{g} \mathrm{m}^{-3}$. Background levels were generally low, aside from the peak of $585 \mu \mathrm{g} \mathrm{m}^{-3}$ in AQM1. AQM2 and AQM3 also showed slightly elevated levels at the beginning of the measurement period. This may have been the result of localised stirring of dust on the floors during the equipment set up, both from the soft nature of the plaster finish on the building floors, and from dust tracked in from the surrounding area.

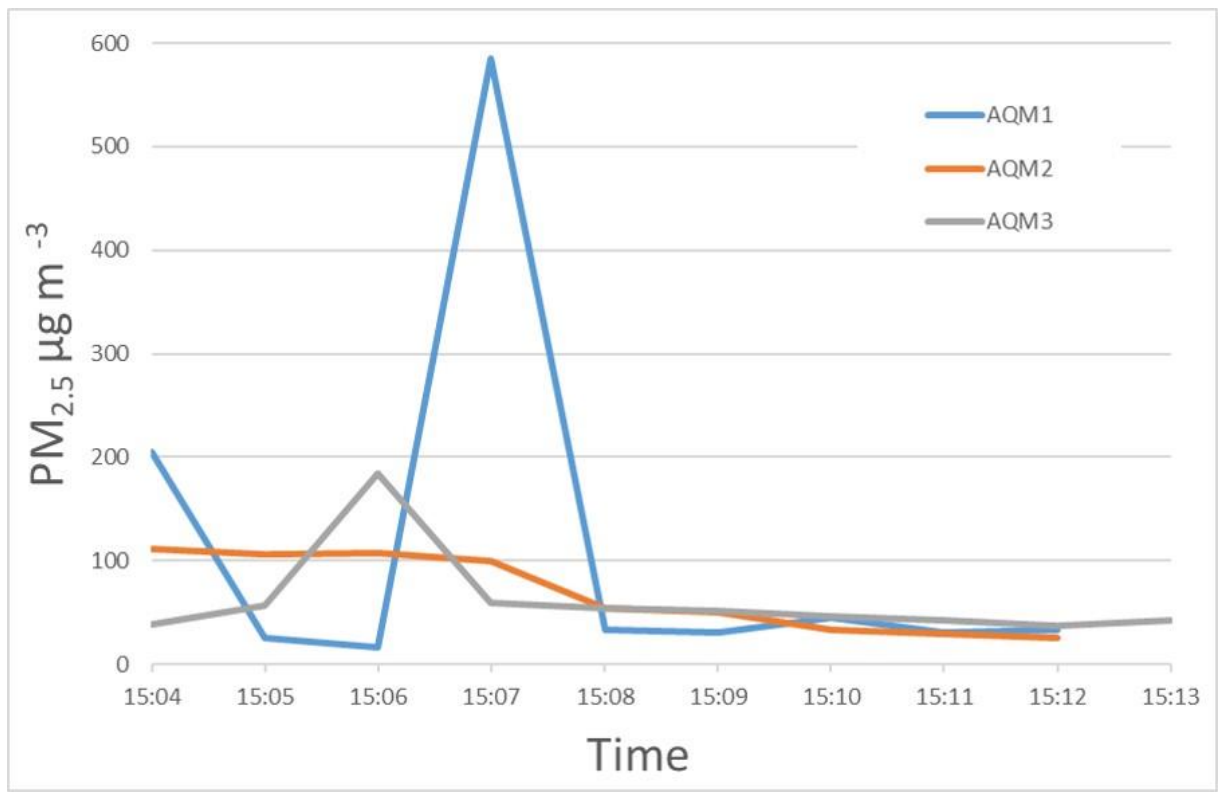

Figure 3: Background PM2.5 levels

\subsection{Test 2: Dung fuel on hearth}

In test 2, dung fuel was burnt on the hearth area in front of the oven. Figure 4 shows the time series data. $\mathrm{PM}_{2.5}$ values for the dung burning experiment climbed rapidly and exceeded the capacity of all three monitors for around 1 hour between 17:28 and 18:24. The highest level of 150,000 $\mu \mathrm{g} \mathrm{m}^{-3}$ was recorded by AQM3, which is the capacity of the machine. It is likely that the actual values were higher than this. The indoor pollution exceeded the maximum capacity of $20,000 \mu \mathrm{g} \mathrm{m}^{-3}$ for monitors AQM1 and AQM2 for the majority of the period. After one hour the PM 2.5 levels detected by AQM3 
declined rapidly from the maximum value but remained high staying in the range of 4000 to $2590 \mu \mathrm{g}$ $\mathrm{m}^{-3}$ for another hour until the fire burned out completely.

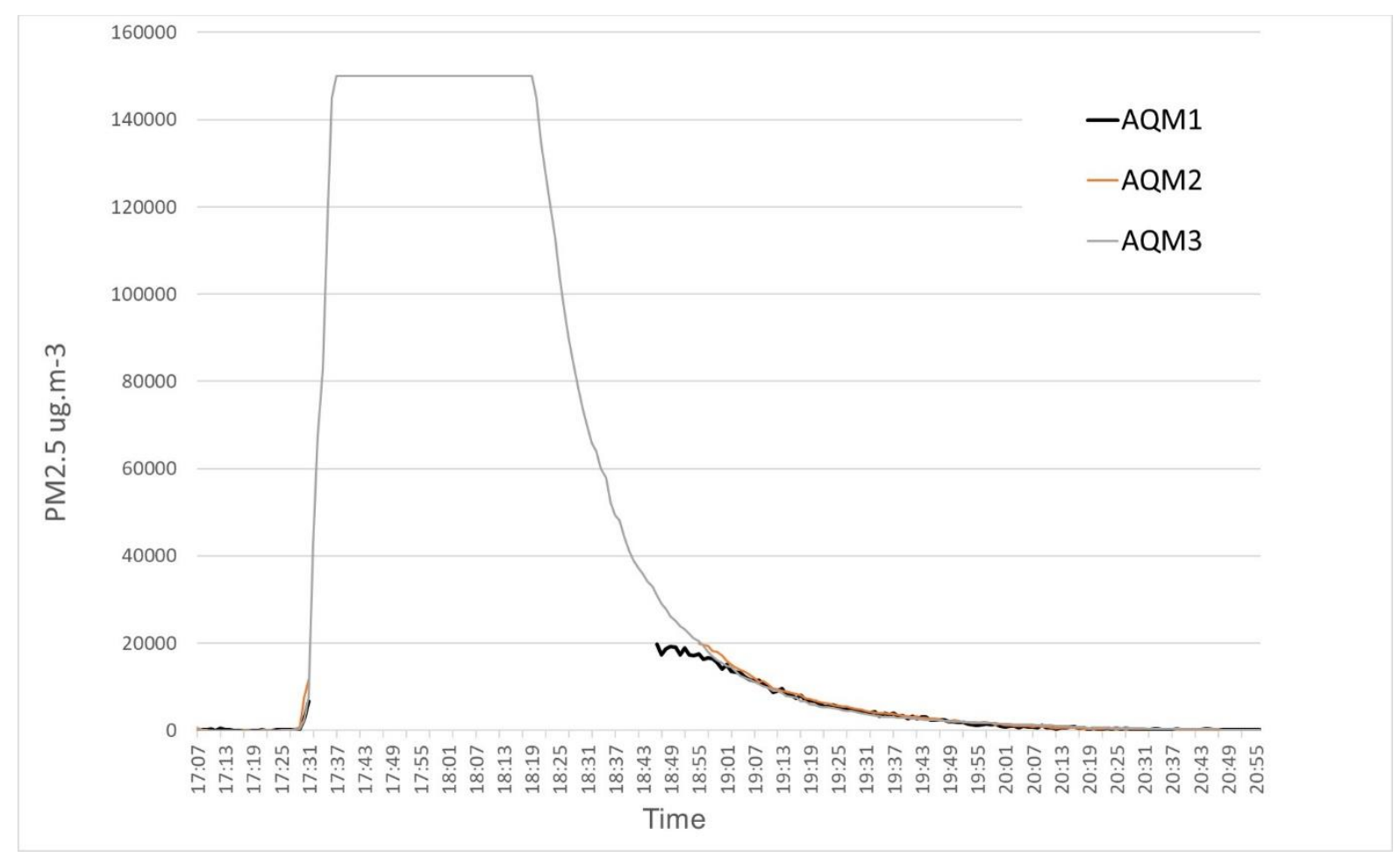

Figure 4: Test 2 Showing $P M_{2.5}$ emissions from a dung fuel fire on hearth

\subsection{Test 3 - wood fuel in oven}

In Test 3 wood was burned for 2 hours 36 minutes. Figure 5 depicts the time series of PM 2.5 . All monitors show a broadly similar pattern of emissions, with a rapid, stepped increase to the maximum value after c. 20 mins, remaining at this level for around one hour before gradually decreasing over a further one-hour period, and a more rapid reduction for 45 mins. AQM2 received highest particulate levels of $19980 \mu \mathrm{g} \mathrm{m}^{-3}$ at 7:14, and AQM1 received a maximum value of $18351 \mu \mathrm{g} \mathrm{m}^{-3}$ at 7:23. AQM3 recorded highest value of $25,300 \mu \mathrm{g} \mathrm{m}^{-3}$ at 7:38. The maximum levels surpassed the capacity of AQM2 for a period between 7.15-7.40 am, though given the overall trend in comparison with AQM1 and AQM3, this likely remained around 20,000 during this period. AQM2 was located further away but directly in front of the oven opening, whereas AQM1 was located to the side (Figure 2).

The fire was extinguished at 8:20 at which point the particulate pollutant levels decreased until the end of the test, settling out after around one hour. A slight upraised trend in the graph was likely due to the smouldering effect caused after the fire was extinguished. 


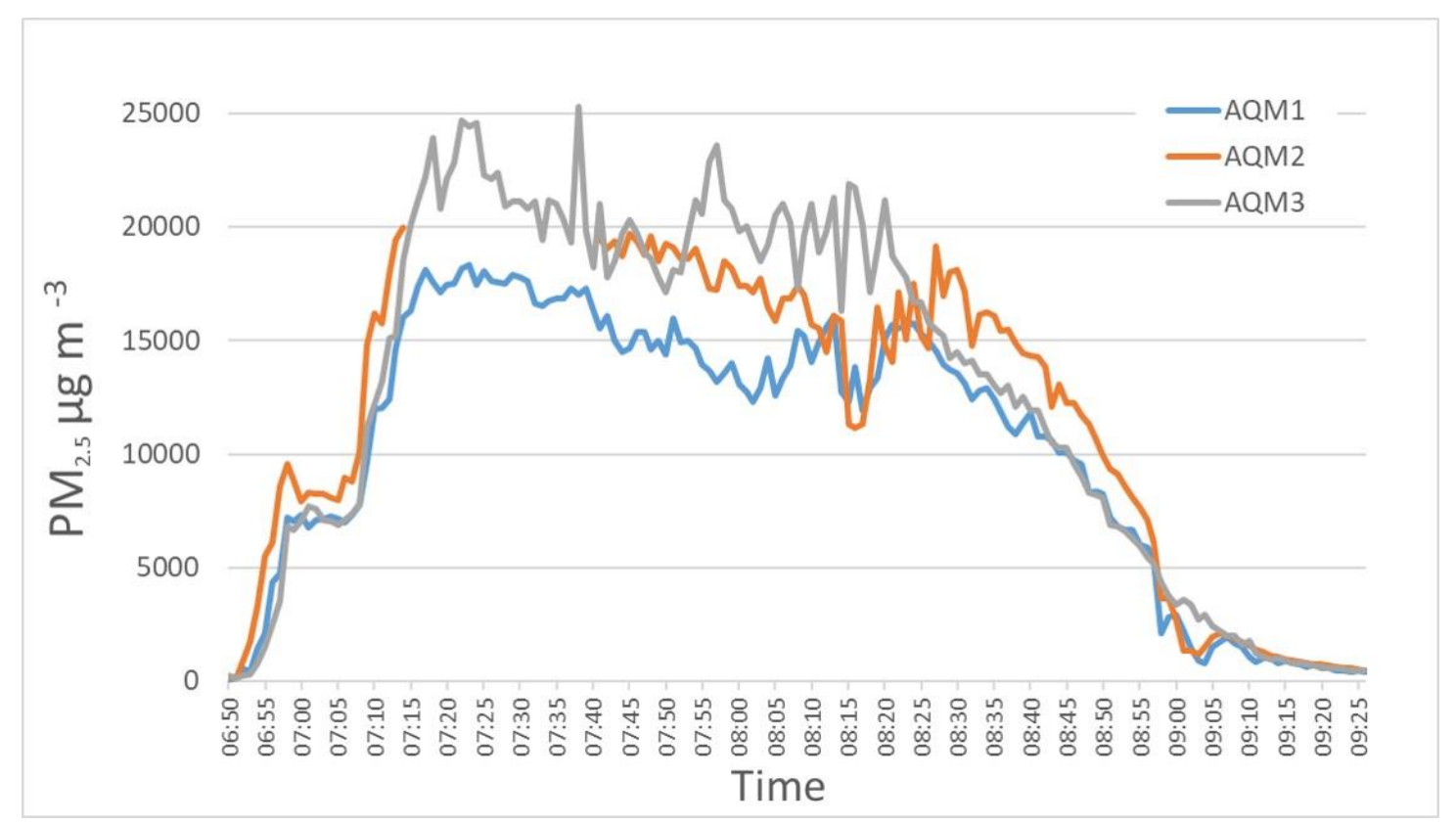

Figure 5: Test 3 Showing PM 2.5 emissions from burning wood fuel in the oven

\subsection{Test 4-Mixed fuel fire in oven}

Figure 6 shows the time series of PM 2.5 in test 4. AQM1 and AQM2 were unable to capture the recordings where the pollution was greater than $20000 \mu \mathrm{g} \mathrm{m}^{-3}$, which occurred for two periods, the first around 12:02 pm and continued for forty-two minutes, and the second around 12:47 pm for one hour. The highest value attained by this test was captured by the two different monitors were 19540 $\mu \mathrm{g} \mathrm{m}^{-3}$ at 1:22 $\mathrm{pm}$ and $17950 \mu \mathrm{g} \mathrm{m}^{-3}$ at 1:43 pm respectively. As the concentration started to decrease after 1:44 pm, the period after this time was considered as the fire decaying period. While AQM1 recorded lowest value at the end of the study, the other monitor detected in the decaying time of the fire. AQM3 recorded a similar trend as the first two monitors, however this monitor was once again able to record all the measurements due to its higher capacity (Figure 8 and 9). The emissions initially followed the same pattern as the dung fuel in test 2 with a rapid increase to very high levels in $\mathrm{PM}_{2.5}$ achieving highest levels of $149,000 \mu \mathrm{g} \mathrm{m}^{-3}$ at $12: 17 \mathrm{pm}$ and 12:23 $\mathrm{pm}$. This was followed by a drop off after 30 minutes, 20 minutes at a steady level around 20-30,000 $\mu \mathrm{g} \mathrm{m}^{-3}$ with a second rapid increase, and stepped decrease. The overall duration of burning was around 2 hours.

As Çatalhöyük is a World Heritage Site it attracts a lot of tourists. It should be noted that Test 4 was disrupted for approximately 10 minutes when a tour group briefly opened the door of the experimental building, and some of the smoke is likely to have escaped from the outlet. This could explain the sudden drop observed in the emissions, and the resurgence that followed after the door was closed. 


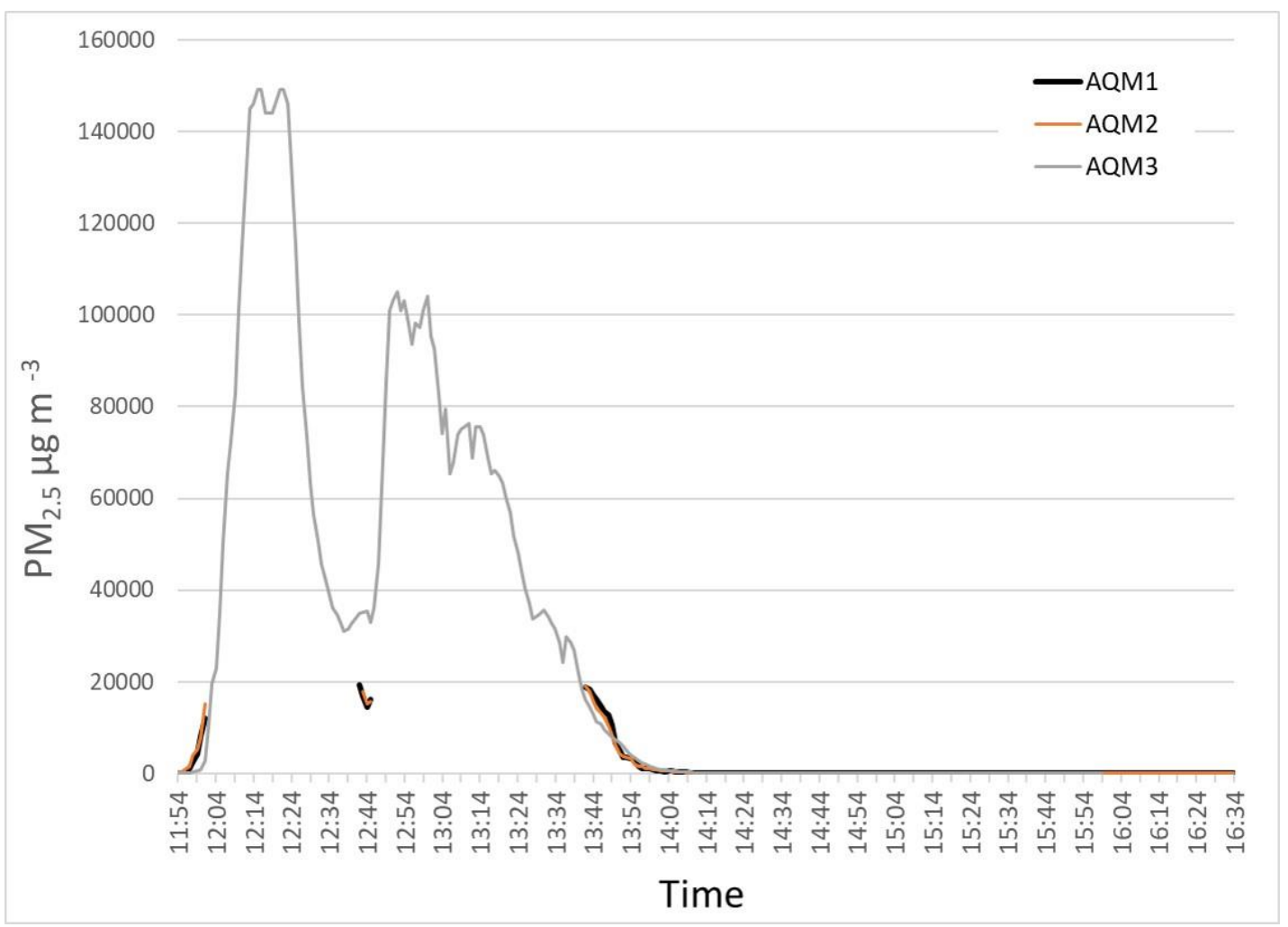

Figure 6:Test 4 showing Test 3 Showing PM 2.5 emissions from burning mixed fuel in the oven

\subsection{Test 5: Wood, refuelled}

The fire was ignited at around 19:19 and to increase its intensity, two wooden logs were added after three minutes. After this point, the pollutant level started to increase and AQM1 and AQM2 were unable to record the readings at 7:34 pm for three minutes as the quantity exceeded the instrument's capacities. The peak value attained by this test was captured by the two different monitors were 19733 $\mu \mathrm{g} \mathrm{m}^{-3}$ at 7:39 $\mathrm{pm}$ and $18115 \mu \mathrm{g} \mathrm{m}^{-3}$ at 7:43 $\mathrm{pm}$ (Figure 7).

AQM3 recorded a similar trend as the first two monitors and this monitor was successful to capture all the $\mathrm{PM}_{2.5}$ quantities. After fire ignition at 7:19 pm, the levels escalated and reach a peak of $36900 \mu \mathrm{g}$ $\mathrm{m}^{-3}$ at 7:38 $\mathrm{pm}$ and then started to decrease rapidly. The peak values were detected for a period of 30 minutes, before settling in to a fluctuating level between 5-7000 $\mathrm{\mu g} \mathrm{m}^{-3}$ for around two hours followed by a gradual decline. The monitors were left to record the emissions overnight after the fire had burnt out. 


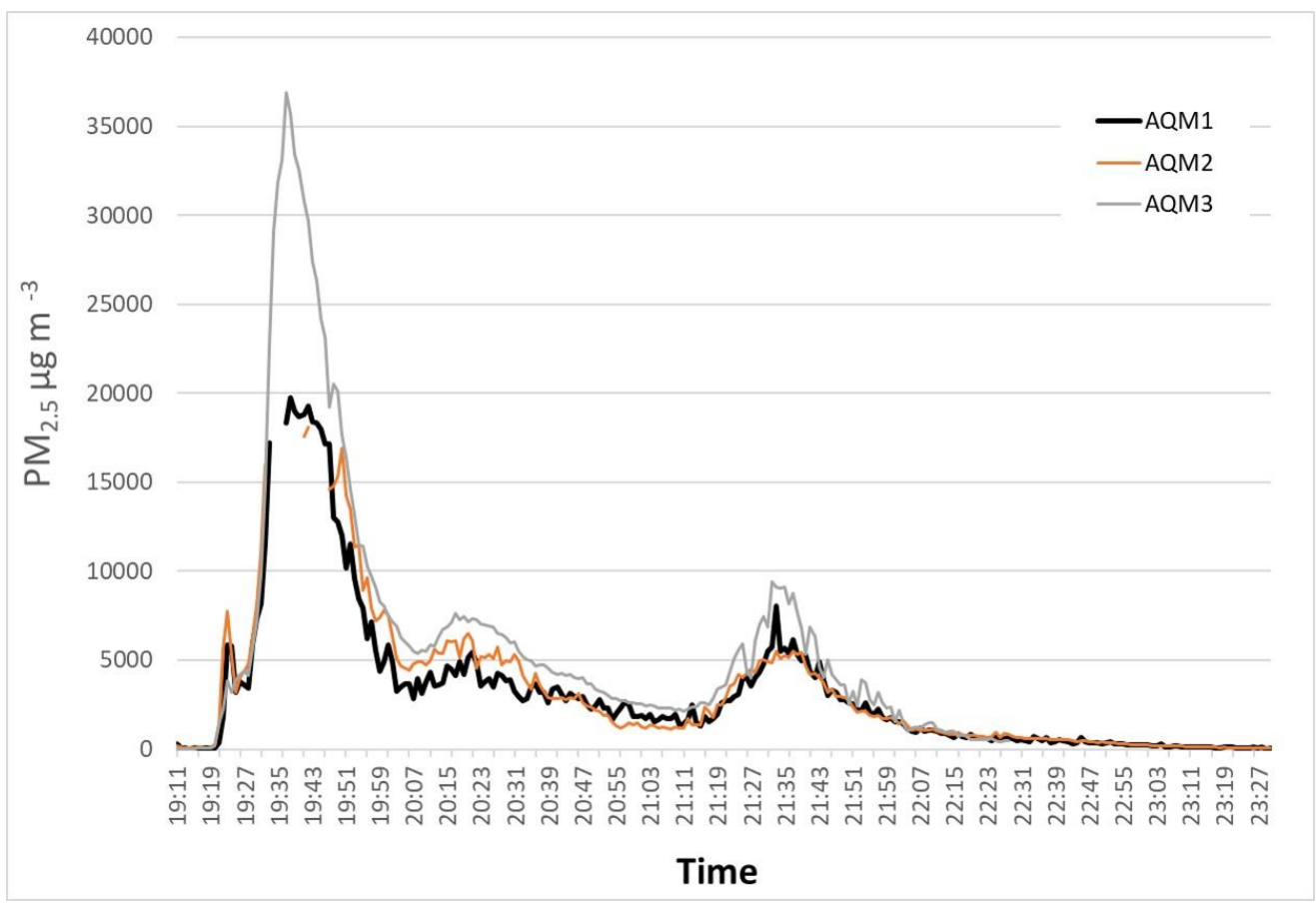

Figure 7: Test 5 Showing PM 2.5 emissions from burning wood fuel in the oven, with a refuelling episode

\section{Discussion}

The first point to note is the background measurements. Whilst these were very low in comparison to the fuel burning episodes, there is clearly a level of environmental input.

\subsection{Comparison between experiments and different fuel types}

Tests 3-5 were conducted to compare the emissions from wood, mixed dung and wood, and wood refuelled, when burning in the oven. The maximum for all tests was in the region of $18-20,000 \mu \mathrm{g} \mathrm{m}^{-3}$ for AMQ1 and AMQ2, very close to the limit of detection of the monitors. The maximum recorded by AQM3 for tests 3, 4 and 5 was $25,000 \mu \mathrm{g} \mathrm{m}^{-3}, 149,000 \mu \mathrm{g} \mathrm{m}^{-3}$ and $36,900 \mu \mathrm{g} \mathrm{m}^{-3}$ respectively. All values are a similar order of magnitude aside from test 4 where dung and wood are mixed, when the emissions are more than four times that of wood alone. The capacity of all three monitors was exceeded for at least part of the fuel burning episode in test 2, meaning the exact maximum figure is unknown, but in excess of $150,000 \mu \mathrm{g} \mathrm{m}^{-3}$.

AQM3 showed that test 2 containing dung as the fuel is the highest emitter of the $\mathrm{PM}_{2.5}$ pollution. This was followed by the test 5 comprising the mixture of wood and dung fuel, burnt in the oven. The maximum for test 2 on the hearth was $>150,000 \mu \mathrm{g} \mathrm{m}^{-3}$ and test 5 was $36,900 \mu \mathrm{g} \mathrm{m}^{-3}$, suggesting that the oven did have a reducing effect on the emissions received by the AQMs, though it is also noted that the mix of fuel types may also account for a lower signal than when the dung was burnt by itself. 


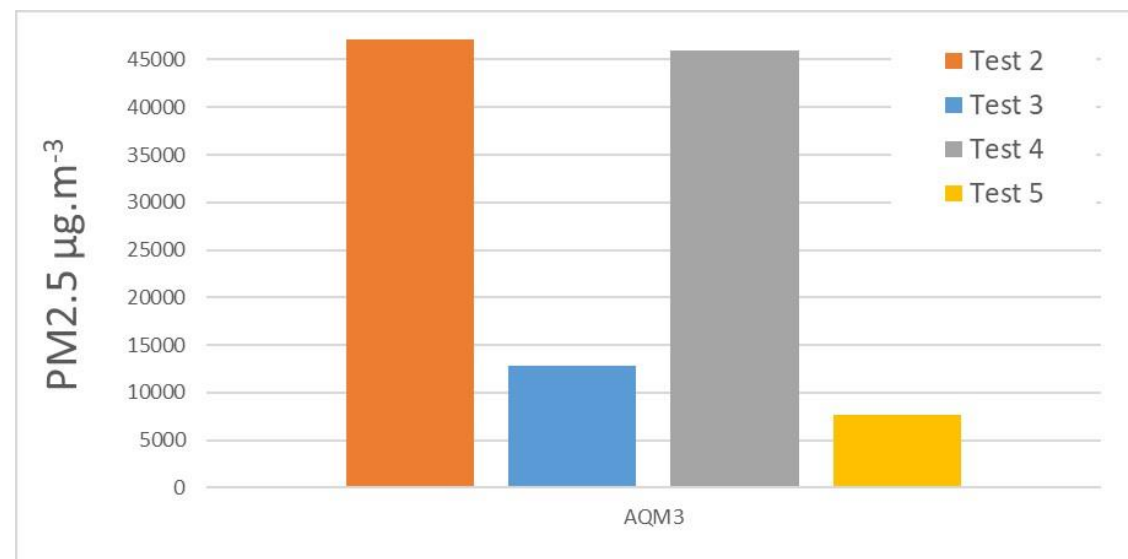

Figure 8: Average PM 2.5 values over 2 hour period detected using AQM3

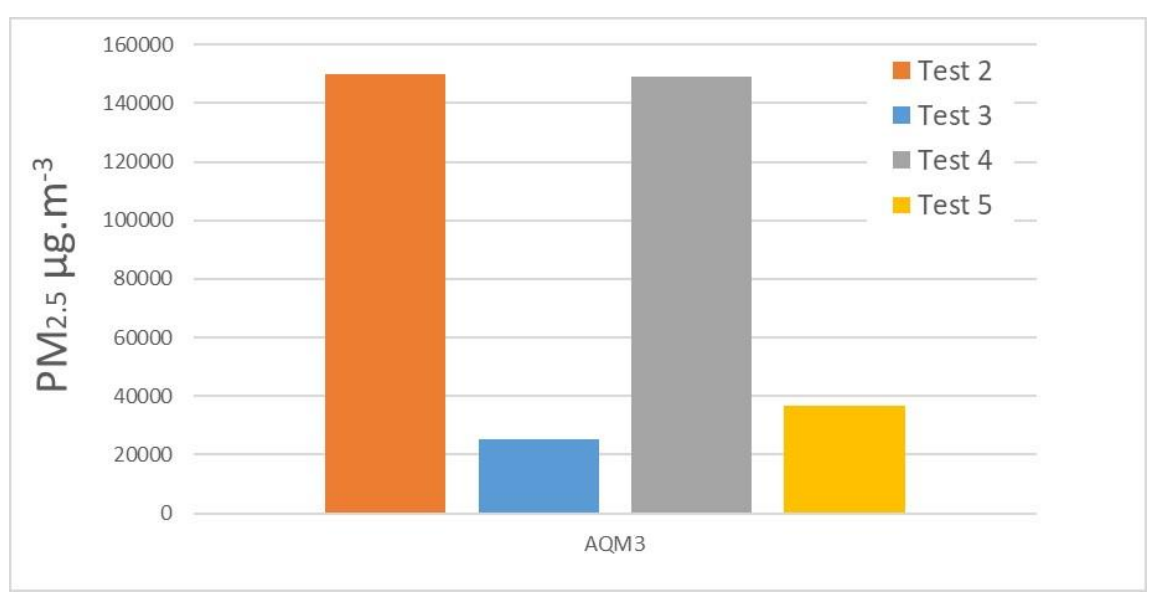

Figure 9: Maximum PM 2.5 values detected by AQM3

Dung was observed to be the highest producer of $\mathrm{PM}_{2.5}$ in this investigation, when compared with wood or mixed fuel, producing maximum values more than four times that of wood. This observation matches previously reported comparisons of dung and wood, for example, Joon et al. (2011) compared dung, wood and other fuels burnt in traditional and modern stoves in India. In their study the maximum values from dung were $11,000 \mu \mathrm{g} \mathrm{m}^{-3}$ and averaged $774 \mu \mathrm{g} \mathrm{m}^{-3}$ over 24 hours, compared with wood at $223 \mu \mathrm{g} \mathrm{m}^{-3}$. Dung mixed with wood (test 4) showed similar high levels of PM 2.5 even when this was burnt inside the oven rather than outside the oven on the hearth. Wood as the sole fuel source (test 3 and 5) produced lower levels of $\mathrm{PM}_{2.5}$, but still at levels much higher than the background levels.

The difference between the wood and dung is likely due to the physical properties of the two materials, and the varying composition of the particulate matter produced during burning. PM 2.5 contains various compounds that trigger a response in the cells of the lungs, and experiments in mice have shown that the pulmonary response differs when exposed to smoke from wood or dung, with a significantly higher inflammatory response from dung smoke. Dung produces a greater volume of PM 2.5 per mass of fuel, contains higher levels of microbes, and a greater oxidative capacity (Sussan et al. 2014). Analysis of wood and dung smoke has shown that wood smoke consists of $\mathrm{C}_{\mathrm{x}} \mathrm{H}_{\mathrm{y}} \mathrm{O}_{\mathrm{z}}$ compounds deriving from lignin pyrolysis (Fleming et al. 2018). Dung smoke on the other hand has a much higher chemical complexity, and is dominated by $\mathrm{C}_{\mathrm{x}} \mathrm{H}_{\mathrm{y}} \mathrm{N}_{\mathrm{w}}$ compounds due to the high nitrogen content (Fleming et al. 2018). After combustion, the by-products of dung include high amount of mineral matter, largely silica. Silica is due to the high phytolith content from the diet and is also 
observed in archaeological dung (Portillo et al. 2020). The silica content presents a great threat to the human health. Silica is highly fibrogenic and when inhaled it causes toxicological effects on the lung tissues (Li et al 2019).

\subsection{The impact of house structure and ventilation}

It is known in modern studies of air pollution that building configuration and ventilation plays a key role in determining levels of exposure to fuel burning by products (Balcan, et al 2016). Multiple studies indicate that domestic heating is a greater cause of pollution than industry, particularly during winter due to people spending more time indoors with fires for heating (Taşdemir et al 2005, Özden et al 2008, Mudway et al. 2005). The structure of buildings at Çatalhöyük is unusual from a modern perspective in that no evidence for windows or doors has been uncovered. It is thought that inhabitants entered and exited the building through an opening in the roof. A typical house at Çatalhöyük had a domed oven set against the south wall, located beneath an opening in the roof. The way the ovens functioned is unclear - there is no archaeological evidence for chimneys or flues, and multiple attempts at lighting fires in the experimental house inevitably have resulted in the building becoming rapidly filled with smoke (Shillito et al. 2017, Eddisford et al. 2009).

A similar situation was observed when Skov et al., (2000) conducted experiments in a reconstructed a Danish Iron Age structure to examine indoor air pollution. In this structure, a similar type of thatched roof was present and the outlet for the smoke created was through the thatched roof and louvers in the ridge and the gables. As a result, a lot of smoke built up inside which caused eye and throat irritation of the researchers. This study measured levels of NO and VOC rather than PM 2.5 .

In both Catalhoyuk and the Danish Iron Age structure, the infrastructure of the house is likely to play an important role. Both are enclosed with no structure for ventilation. A simialr situation was observed when indoor pollution was evaluated in traditional Tibetan village households that use yak dung as fuel for cooking and heating, especially during winter. The average $\mathrm{PM}_{2.5}$ concentration was found to be $956 \mu \mathrm{g} \mathrm{m}^{-3}$. The lack of ventilation in the houses along with the stove design were thought to be responsible for the poor indoor air quality. In addition, the yak dung was also left uncovered in the sun and snow event in the night times which led to higher moisture content of the dung. The higher moisture content affected its combustion efficiency and difficulty in reducing the produced black carbon and $\mathrm{PM}_{2.5}$ (Xiao et al 2015).

In comparison, another fuel burning experiment at the Lejre Center in Denmark, researchers carried out a similar experiment in reconstructions of $17-19^{\text {th }}$ century farmhouse buildings. In these buildings the hearths were located in the middle of the building with total dimensions of $13 \times 3.7 \mathrm{~m}$, ceiling height of $1.9 \mathrm{~m}$. In this case a $6 \mathrm{~m}$ high chimney was also present. At Lejre the $\mathrm{PM}_{2.5}$ had a daily average $138-1650 \mathrm{\mu g} \mathrm{m}^{-3}$ inside the hearths and 21-160 in the adjacent living rooms. Calculated daily exposure for individuals in close proximity to the hearth averaged $196 \mu \mathrm{g} \mathrm{m}^{-3}$ of PM 2.5 . (RhylSvensen et al. 2010). Measurements of air distribution at Lejre showed that the chimneys created a draw effect that quickly removed the smoke from the hearth area, thus high levels of exposure would only have impacted individuals in very close proximity to the fire. Interestingly, the PM 2.5 levels near to the fire were still lower than those observed in out study, or by Skov et al (2000).

In our study, we focused analysis on the 2-4 hour period when the fire was actively burning, to avoid distorting the average by including a long 'tail' of background measurements. In test 5 the monitors were left running for 10 hours, some 7 hours after the fire burnt out. If the full duration of measurements over the 10 hours are included, the average reading for that day would be $1336-1839$ $\mu \mathrm{g} \mathrm{m}^{-3}$. At Çatalhöyük, the lack of a proper chimney, combined with a single small room combining 
living space and the hearth, means that all inhabitants would have been exposed to these high levels, not just those working in close proximity to the fire.

\subsection{Implications for understanding fuel and use of space in buildings at Çatalhöyük}

Fuel use at Çatalhöyük has been studied extensively. The use of dung fuel has been identified through micromorphological analysis and the presence of dung ash, and also in macrobotanical assemblages where charred dung pellets and weed seeds from animal consumption (Matthews 2005, Shillito et al 2011, Bogaard et al. 2013). Combined micromorphology and botanical data show that dung, wood and reeds were mixed. Kabucku's (2018) analysis of wood charcoal identifies features such as fungal hyphae and collapsed vessels and boreholes, which suggest wood was collected as deadwood and/or stored before being burned.

Large ash deposits in external areas shows that burning was also occurring outside the buildings. Whilst this would also have generated large volumes of $\mathrm{PM}_{2.5}$, exposure may not have been as intense due to better circulation of air, though still contained within an area relatively enclosed in many cases, and the settlement configuration and density also need to be considered. Microcharcoal is seen in many deposits at Çatalhöyük (Shillito and Matthews 2013, Matthews 2016), and likely to indicate a general background of particulate matter from frequent fuel burning at the site.

Whilst the wood charcoal data is available for the length of occupation, data on levels of dung use are not as extensive. A systematic comparison of ash deposits relating to fuel use is needed to properly assess whether the types of fuel and their location changed over time, but current data indicates that dung was more likely to be used in outdoor fires (Portillo et al. 2020). It is noted that outdoor areas are still at risk, and that exposure to air pollution often occurs in the environment surrounding a building, not just indoors. In buildings where smoke is ventilated through chimneys, this often impacts the ambient levels in the area surrounding the buildings (Smith and Pillarisetti 2017).

In our experiments, emissions continued to remain high up to 40 minutes after the fires has burnt out afterwards. Test 3 indicates greater exposure directly in front of the oven, though overall similar levels to the side of the opening, suggesting that the relative position of a person in relation to the fire had only a minimal impact on exposure. The positioning of all the three monitors influenced the variations observed in the results, with individuals who spent periods of time in closer proximity to the fire were at greater risk, however the small size of the rooms meant that the area of close proximity covered most of the living area, and although there was some variation between monitors, levels were extremely high in all AQM positions.

The fires have been lit in the experimental buildings on numerous occasions, and each time it has been noted how smoky the room gets, and it is usually impossible to stay in the room due to the high levels of smoke. It could be that the inhabitants developed a tolerance to the high levels. Other researchers have suggested that the indoor fires would not have had high levels of fuel being burnt in them, and that only embers would have been transferred from open fires outside (Eddisford et al. 2009). However, this would not account for observations of smoke on the walls observed by Matthews (2005) and others. Soot is a carbon residue that forms during incomplete combustion, and deposits within minutes on walls close to fires. Research at Çatalhöyük has identified cycles of soot layers in some buildings with seasonal exterior and interior variations in soot accumulations showing evidence for seasonal oven use (Arkun 2003, Anderson et al. 2013, Matthews 2005, 2008, 2012, 2016).

These observations have also been made at other Neolithic settlements indicating this was likely widespread (Matthews 2012, Matthews et al. 2014). It has been suggested people at Çatalhöyük 
replastered their walls every month or so, in order to stop the walls being covered in soot and smoke build up from the hearth and oven in the house and to keep a clean appearance (Matthews 2008). The build-up of soot on walls has been suggested as a reason for frequent refinishing of plaster walls and has been observed at other archaeological sites, for example Smith (1952:19 in Meyers 2007) describes a similar process in southwest houses and Slater (1999) describes replastering to cover soot layers on kiva. The soot layers were concentrated in upper parts of the kiva due to the upward movement of hot air and smoke.

\subsection{Implications for respiratory health at Çatalhöyük}

A recent report indicates that combustion of 2-3 $\mathrm{kg}$ of biofuels such as wood or peat produces particulate matter equivalent to driving a modern diesel car for thousands of kilometres (Smith and Quinn 2020). Another comparison is that $6 \mathrm{~g}$ of $\mathrm{PM}_{2.5}$ are produced per hour when burning wood, the equivalent to smoking 400 cigarettes. So it is almost certain that burning fuel indoors at Çatalhöyük exposed inhabitants to unsafe levels of particulates. The observations in this experiment therefore raise a number of interesting questions concerning fuel use in the Neolithic settlement, and the impact this would have had on the health of the inhabitants.

Early studies of human skeletal material at Çatalhöyük identified black carbon residues on the interior surface of ribs from three individuals, which was interpreted as evidence for anthracosis (Andrews et al 2005, Birch 2005). Upon re-examination, however, it is debatable whether these black deposits represent in vivo accumulation of soot within the lungs or are post-depositional in nature. In any case the number of individuals affected by these residues is very low. Unequivocal skeletal evidence for respiratory disease has not been reported, however there are some observations that could relate to chronic lung disease.

Two studies by Larsen et al $(2015,2019)$ review the health of the population over its $1000+$ year occupation from an osteoarchaeological perspective. In the Early period (7100-6700 cal BCE), the population was small and hypothesised to consist of only a few households, and grew to perhaps 3500-8000 individuals during the Middle period (6700-6500 cal BCE), the peak population size. These estimations are based on the number and size of houses (Cessford 2005). In the Late period (6500-5950 cal BCE) the population appears to have decreased; buildings were more dispersed and there was more open space than in previous periods.

Osteoperiostitis is a generalised inflammatory response to infection and is present in the Çatalhöyük assemblage, and largely associated with lower limbs (Larsen et al. 2019). There is a significant change over time, with the population showing more osteoperiostitis in the Middle period, with a rapid decline in the Late period (prevalence is 33 to 26 to $19 \%$ in the Early, Middle, and Late periods, respectively (Larsen et al. 2019: 6). In terms of age-related patterning, a previous analysis revealed that sub-adults show the highest levels in the Early period, a slight decline in the Middle period, and a greater decline in the Late period (Larsen et al. 2015: 54). In the sub-adult category, neonates and infants have a considerably higher prevalence of osteoperiostitis, which likely represents this age group's increased risk for infection as a result of their immature immune systems.

Both children and adults appear to have had adequate diets, with few signs of nutritional stress (Larsen et al. 2015: 50). The population does show an elevated prevalence of dental caries, which is linked to consumption of carbohydrates (Larsen et al. 2015: 58). Periostitic lesions are therefore unlikely to relate to nutritional stress, given that all other indications suggest good availability of food. Larsen and co-workers (2019) attribute periosteal reactions to increased population density, which is believed to have promoted the transmission of pathogens and increased the likelihood of tissue infection from cuts, Larsen et al. 2019 suggest the prevalence of subperiosteal lesions on tibial 
diaphyses in farmers compared to foragers globally is a result of localised bacterial infection. Perhaps this is also linked to chronic smoke exposure.

One difficulty is that osteoperiostitis is non-specific so cannot be clearly linked to a specific infection or disease, but given the indirect evidence from our experiments, an additional explanation for these observations could be that the periosteal lesions are a result of chronic exposure to $\mathrm{PM}_{2.5}$. The inhalation of $\mathrm{PM}_{2.5}$ is a hazard because the small particles can travel deep into the lungs where they become embedded in the tissue and can even enter the blood stream, triggering an inflammatory response outside the lungs. In modern studies, increased bone deposition on long bones has been linked specifically to lung disease (West 2012).

Exposure to $\mathrm{PM}_{2.5}$ is also linked to increased susceptibility to infection, and it could be that these factors are both linked to the bone lesions. Staphylococcus aureus for example, a commonly occurring skin bacteria, is known to be altered by exposure to black carbon in smoke, and the particulates can transfer the bacteria from the nasopharynx to the lungs (Hussey et al. 2017). As well as the direct adverse effects of indoor air pollutants, exposure can also lead to a weakened immune system and increased vulnerability to respiratory tract infection, and other indirect impacts such as low birth weights (Kurmi et al. 2012). Although it is not possible with the current data to make a direct link between the osteoarchaeological record and respiratory disease attributed to fuel burning, however our experimental work strongly suggests this possibility, if we assume that people were spending time indoors on a regular basis.

Larsen and co-workers (2015) also discuss osteoarthritis at Çatalhöyük, which has a prevalence of $27.3 \%$ in young adults aged $20-29$, increasing to $82 \%$ in older adults. Osteoarthritis is typically attributed to manual stress, and there is a general reduction in prevalence over time, which is interpreted as a decrease in workload (Larsen et al. 2015: 46). A subcategory of osteoarthritis called hypertrophic osteoarthropathy is known to occur with periostitis of long bones (distal tibia, femur and radius) and clubbing of fingers and toes (Vandemergel et al. 2004), though clubbing may not always be present (Izumi et al 2010). 80-90\% of hypertrophic osteoarthropathy cases are associated with lung cancer and chronic pulmonary disease (West 2012), however none of the cases of osteoarthritis at Çatalhöyük belong to this specific category of secondary osteoarthritis

Davies-Barrett et al. 2019 describe a method for describing periosteal growth on the ribs, which is linked specifically to lung inflammation from respiratory disease. Reactive bone lesions on the visceral surfaces of ribs are described rarely among the Neolithic Çatalhöyük skeletal assemblage, although they have not been studied systematically. We suggest that this could be an area of future enquiry.

\section{Conclusions}

All of the burning activities within the experimental Çatalhöyük house created unsafe levels of $\mathrm{PM}_{2.5}$, with the use of dung either by itself or mixed with wood, having around four times higher levels of $\mathrm{PM}_{2.5}$ than wood alone. Even though the pollution created by the wood was comparatively less than that of the dung, the $\mathrm{PM}_{2.5}$ pollution produced by both fuels overall exceeded the European standard limits and the WHO limits of $25 \mu \mathrm{g} \mathrm{m}^{-3}$ and $20 \mu \mathrm{g} \mathrm{m}^{-3}$ respectively by many orders of magnitude. The lack of openings or chimney meant little ventilation was present, leading to an accumulation of particulates. This is almost certain to have had adverse effects if people were occupying the buildings when the fires were burning.

PM in modern contexts leads to direct and indirect health impacts, and increases susceptibility to other disease. If people were burning fuels regularly indoors in the Çatalhöyük buildings, they 
certainly would have been exposed to extremely high levels of unsafe $\mathrm{PM}_{2.5}$, and extended exposure would have had an impact on respiratory health. It may be expected that such an impact would be detected in the human remains, however, clear osteological evidence is lacking. Whilst several nonspecific indicators are observed, some of which could potentially be linked to lung disease, preservation issues and their non-specific origins make it difficult to be certain whether these bony lesions are associated with pulmonary disorders or other types of disease. Long bone periostitis and arthritis observed in the human remains have previously been attributed to general infection and workload. We propose that these may also be linked to lung disease through chronic exposure to exceptionally high levels of $\mathrm{PM}_{2.5}$.

Understanding the exposure-response relationship (i.e. the relationship between differing levels of exposure to air pollution and the actual incidence of disease) is difficult in modern contexts due to the short term nature of most studies (Ezzati and Kammen 2002). Whilst the relationship between biomass burning and increased indoor air pollution is well known, the mechanisms are poorly understood. There have been limited studies on the impacts of exposure to sustained high levels of air pollution on health and mortality (Huang et al 2018). A study over 7 years in China indicated that duration effects increase the effect and are more accurate than measurements of pollution on isolated days.

The extended chronology of the archaeological record has the potential to help understand the longterm (>lifetime) relationship between health and the built environment, and the potentials are just beginning to be explored (Shillito et al. 2017). Collaborative research involving archaeology and environmental engineering offers a new approach to studying such questions. Future research will expand these experiments to investigate a wider range of scenarios.

\section{Acknowledgements}

Funding: This research was funded by a Wellcome Trust Seed Award 2017-18, 205719/Z/16/Z. The authors declare no conflict of interest. A spreadsheet containing all data from this study is included as Supplementary Information. Author contributions: LMS Funding acquisition; LMS and AN Conceptualization; AN Methodology; LMS and HM Investigation; AN and AB Data analysis and curation; LMS, AB, SDH, Writing, Original draft preparation; LMS, AB, SDH, HM Writing, Review and Editing.

\section{References}

Akgun, M., Araz, O., Ucar, E. Y., Karaman, A., Alper, F., Gorguner, M., \& Kreiss, K. (2015). Silicosis Appears Inevitable Among Former Denim Sandblasters: A 4-Year Follow-up Study. Chest, 148(3), 647-654. https://doi.org/10.1378/chest.14-2848

Anderson, E., Almond, M. and Matthews, W. (2014) Analysis of wall plasters and natural sediments from the Neolithic town of Çatalhöyük (Turkey) by a range of analytical techniques. Spectrochimica Acta Part A: Molecular and Biomolecular Spectroscopy, 133. pp. 326-334

Andrews, P. Molleson, T. and Boz, B. (2005). The human burials at Çatalhöyük Hodder (Ed.), Inhabiting Çatalhöyük McDonald Inst, Cambridge pp. 261-78

Arkun, Burcum Hanzade (2003). Neolithic Plasters of the Near East: Catal Hoyuk Building 5, a Case Study.(Masters Thesis). University of Pennsylvania, Philadelphia, PA 
Balcan, B., Akan, S., Ozsancak Ugurlu, A., Ozcelik Handemir, B., Bagci Ceyhan, B. and Özkaya, Ş. (2016). Effects of biomass smoke on pulmonary functions: a case control study. International Journal of Chronic Obstructive Pulmonary Disease, Volume 11, pp.1615-1622.

Banerjea, R.Y., Bell, M., Matthews, W. et al. 2015. Applications of micromorphology to understanding activity areas and site formation processes in experimental hut floors. Archaeol Anthropol Sci 7, 89-112 https://doi.org/10.1007/s12520-013-0160-5

Bayliss, A., Brock, F., Farid, S., Hodder, I., Southon, J. and Taylor, RE. (2015). Getting to the bottom of it all: A Bayesian approach to dating the start of Çatalhöyük. Journal of World Prehistory 28:1-26

Berna, Francesco; Goldberg, Paul; Horwitz, Liora Kolska; Brink, James; Holt, Sharon; Bamford, Marion; Chazan, Michael (2012). Microstratigraphic evidence of in situ fire in the Acheulean strata of Wonderwerk Cave, Northern Cape province, South Africa. Proceedings of the National Academy of Sciences. 109 (20): E1215-20

Birch, W. (2005). A Possible Case of Shortness of Breath at Çatalhöyük - Black Lungs. In Hodder, Inhabiting Çatalhöyük Cambridge: McDonald Inst/BIAA pp593-596

Bogaard A, Charles M, Livarda A, Ergun M, Filipović D, Jones G (2013) Archaeobotany of the midlater occupation levels at Neolithic Çatalhöyük. In: Hodder I (ed) Humans and landscapes of Çatalhöyük: reports from the 2000-2008 seasons. Monographs of the Cotsen Institute of Archaeology, Los Angeles, pp 93-129

Braadbaart, F., van Brussel, T., van Os, B., \& Eijskoot, Y. (2017). Fuel remains in archaeological contexts: Experimental and archaeological evidence for recognizing remains in hearths used by Iron Age farmers who lived in peatlands. The Holocene, 27(11), 1682-1693.

https://doi.org/10.1177/0959683617702231

Cessford, C. 2005. Estimating the Neolithic population of Çatalhöyük. In, Hodder, I. (ed.). Inhabiting Çatalhöyük: Reports from the 1995-99 Seasons: 325-28. Cambridge: BIAA/McDonald Institute.

Christensen, J.M. and Ryhl-Svendsen, M. (2015), Household air pollution from wood burning in two reconstructed houses from the Danish Viking Age. Indoor Air, 25: 329-340.

https://doi.org/10.1111/ina.12147

Davies-Barrett, Anna M., Antoine, Daniel \& Roberts, Charlotte A. (2019). Inflammatory periosteal reaction on ribs associated with lower respiratory tract disease: A method for recording prevalence from sites with differing preservation. American Journal of Physical Anthropology 168(3): 530-542.

de Silva P, Evans-Jones G, Wright A, et al. 2003. Physiological periostitis; a potential pitfall. Archives of Disease in Childhood 88:1124-1125.

Düring, B. 2005. Building continuity in the central Anatolian Neolithic: exploring the meaning of buildings at Asikli Höyük and Çatalhöyük. Journal of Mediterranean Archaeology, 18 (1) 3-29

Ekici, A., Ekici, M., Kocyigit, P. and Karlidag, A. (2012). Prevalence of Self-Reported Asthma in Urban and Rural Areas of Turkey. Journal of Asthma, 49(5), pp.522-526.

Eddisford, D., Regan, R. and Taylor, J.S. (2009) The experimental firing of a Neolithic Oven. Pages 159-161 in S. Farid (ed) Çatalhöyük 2009 Archive Report: Çatalhöyük Research Project.

Fleming, L. T., Lin, P., Laskin, A., Laskin, J., Weltman, R., Edwards, R. D., Arora, N. K., Yadav, A., Meinardi, S., Blake, D. R., Pillarisetti, A., Smith, K. R., and Nizkorodov, S. A. 2018. Molecular composition of particulate matter emissions from dung and brushwood burning household cookstoves in Haryana, India, Atmos. Chem. Phys., 18, 2461-2480, https://doi.org/10.5194/acp-18-2461-2018 
Gargett, K. 2017. Experimenting with the Neolithic

http://catalhoyuk.ege.edu.tr/content/experimenting-neolithic

Hardy, K., Buckley, S., Collins, M.J., Estalrrich, A., Brothwell, D., Copeland, L., García-Tabernero, A., García-Vargas, S., De La Rasilla, M., Lalueza-Fox, C., Huguet, R., Bastir, M., Santamaria, D., Madella, M., Fernandez Cortés, A. \& Rosas, A. 2012. Neanderthal medics? Evidence for food, cooking and medicinal plants entrapped in dental calculus. Naturwissenschaften 99: 617-626

Hodder, I. 2006 The Leopard's Tale Thames and Hudson

Huang, J., Pan, X., Guo, X., Li, G. 2018 Impacts of air pollution wave on years of life lost: A crucial way to communicate the health risks of air pollution to the public Environment International 113: 4249

Hussey SJK, Purves J, Allcock N, et al. 2017. Air pollution alters Staphylococcus aureus and Streptococcus pneumoniae biofilms, antibiotic tolerance and colonisation. Environ Microbiol. 2017;19(5):1868-1880. doi:10.1111/1462-2920.13686

Izumi M, Takayama K, Yabuuchi H, Abe K, Nakanishi Y. 2010. Incidence of hypertrophic pulmonary osteoarthropathy associated with primary lung cancer. Respirology 15(5):809-812

Joon, V., Kumari, H., Chandra, A. and Battacharya, M. 2011. Predicting exposure levels of respirable particulate matter (PM2.5) and carbon monoxide for the cook from combustion of cooking fuels. International Conference on Chemistry and Chemical Process IPCBEE vol.10.

Köksal, N., and Kahraman, H. (2011). Acute silicosis in teflon-coated pan manufacturing due to metal sandblasting. International journal of occupational and environmental health, 17(3), 210-213. https://doi.org/10.1179/107735211799042002

Kabukcu, C. (2018). Identification of woodland management practices and tree growth conditions in archaeological fuel waste remains: A case study from the site of Çatalhöyük in central Anatolia, Turkey. Quaternary International, 463B, 282-297. doi:10.1016/j.quaint.2017.03.017

Kurmi OP, Semple S, Simkhada P, Smith WC, Ayres JG (2010) COPD and chronic bronchitis risk of indoor air pollution from solid fuel: a systematic review and meta-analysis. Thorax 65:221-228

Li, J., Yang, H., Sha, S., Li, J., Zhou, Z. and Cao, Y. (2019). Evaluation of in vitro toxicity of silica nanoparticles (NPs) to lung cells: Influence of cell types and pulmonary surfactant component DPPC. Ecotoxicology and Environmental Safety, 186, p.109770.

Matthews, W. (2016). Humans and fire: Changing relations in early agricultural and built environments in the Zagros, Iran, Iraq. The Anthropocene Review, 3(2), 107-139.

Matthews, W. 2005. Life-cycle and life-course of buildings, in: Çatalhöyük Perspectives: Reports from the 1995-1999 Seasons, I. Hodder (Ed.), McDonald Institute for Archaeological Research, Cambridge and British Institute of Archaeology at Ankara pp. 125-149.

Matthews, W. 2005. Micromorphological and microstratigraphic traces of uses and concepts of space, in: Inhabiting Çatalhöyük: Reports from the 1995-1999 Seasons, I. Hodder (Ed.), McDonald Institute for Archaeological Research, Cambridge and British Institute of Archaeology at Ankara, pp 355-398.

Matthews, W. 1998. Report on sampling strategies, microstratigraphy and micromorphology of depositional sequences, and associated ethnoarchaeology at Çatalhöyük, 1998 http://www.Çatalhöyük.com/archive_reports/1998/ar98_06.html 
W. Matthews, C.A.I. French, T. Lawrence, D. Cutler, Multiple surfaces: the micromorphology, in: On the surface: Çatalhöyük 1993-1995, I. Hodder (Ed.), McDonald Institute for Archaeological Research, Cambridge and British Institute of Archaeology at Ankara, 1996, pp. 301-342.

Meyers, E. 2007. Prehistoric Wall Decoration in the American Southwest: A Behavioral Approach. $\mathrm{PhD}$ thesis. University of Arizona. https://repository.arizona.edu/handle/10150/194060

Merra soDa. (2019). Home - www.soda-pro.com. [online] Available at: http://www.sodapro.com/home

Mudway, I.S., Duggan, S.T., Venkataraman, C. et al. Combustion of dried animal dung as biofuel results in the generation of highly redox active fine particulates. Part Fibre Toxicol 2, 6 (2005). https://doi.org/10.1186/1743-8977-2-6

Namdeo, A, Yadav, J, Deshpande, A. (2015). Belief and plausibility of UK pulmonologists on Health Effects due to air pollution: Revisited. International Journal of Health Sciences and Research, Vol. 5, No. $12,346-354$.

Namdeo, A., Tiwary, A. and Farrow, E. (2011). Estimation of age-related vulnerability to air pollution: Assessment of respiratory health at local scale. Env Int. 37: 829-83

Özden, Ö., Döğeroğlu, T. and Kara, S. 2008 Assessment of ambient air quality in Eskişehir, Turkey Env Int 34:678-87

Portillo, M., García-Suárez, A. \& Matthews, W. 2020. Livestock faecal indicators for animal management, penning, foddering and dung use in early agricultural built environments in the Konya Plain, Central Anatolia. Archaeol Anthropol Sci 12, 40 https://doi.org/10.1007/s12520-019-00988-0

Roberts, C.A. (2015). Old World tuberculosis: evidence from human remains with a review of current research and future prospects. Tuberculosis 95(Supplement 1): S117-S121.

Roberts, C.A. (2007). A bioarchaeological study of maxillary sinusitis. American Journal of Physical Anthropology 133(2): 792-807

Ryhl-Svendsen, M, Clausen, G, Chowdhury, Z \& Smith, K 2010, 'Fine particles and carbon monoxide from wood burning in 17th-19th century Danish kitchens: Measurements at two reconstructed farm houses at the Lejre Historical-Archaeological Experimental Center', Atmospheric Environment, vol. 44 , no. 6 , pp. $735-744$

Shillito et al 2011 The microstratigraphy of middens: capturing daily routine in rubbish at Neolithic Çatalhöyük, Turkey. Antiquity 85:1024-38

Shillito, L.-M., \& Ryan, P. (2013). Surfaces and streets: phytoliths, micromorphology and changing use of space at Neolithic Çatalhöyük (Turkey). Antiquity, 87(337), 684-700

Sillar, B. (2000). Dung by preference: the choice of fuel as an example of how Andean pottery production is embedded within wider technical, social and economic practices. Archaeometry, 42(1), pp.43-60.

Skov, H., Christensen, C. S., Fenger, J., Essenbæk, M., Larsen, D., \& Sørensen, L. (2000). Exposure to Indoor Air Pollution in a Reconstructed House from the Danish Iron Age. Atmospheric Environment, 34, 3801-3804.

Slater, ME. 1999 Characterization of Earthen Architectural Surface Finishes from Kiva Q, Cliff Palace, Mesa Verde National Park Colorado, MSc thesis University of Pennsylvania https://repository.upenn.edu/hp_theses/486/ 
Smith, Kr. And Pillarisetti, A. 2017. Household Air Pollution from Solid Cookfuels and Its Effects on Health. In Disease Control Priorities, Third Edition (Volume 7): Injury Prevention and Environmental Health. October 2017, 133-152.

Smith, WJ. And Quinn, C. 2020. Emission factors from domestic -scale solid fuel appliances (EFDOSOF). EPA Research report number 324.

http://www.epa.ie/researchandeducation/research/researchpublications/researchreports/Research_Rep ort 324.pdf

Sparacello, V.S., Roberts, C.A., Canci, A., Moggi-Cecchi, J. \& Marchi, D. (2016). Insights on the paleoepidemiology of ancient tuberculosis from the structural analysis of postcranial remains from the Ligurian Neolithic (northwestern Italy). International Journal of Paleopathology 15: 50-64.

Sparacello, Vitale S., Roberts, Charlotte A., Kerudin, Ammielle \& Müller, Romy (2017). A 6500year-old Middle Neolithic child from Pollera Cave (Liguria, Italy) with probable multifocal osteoarticular tuberculosis. International Journal of Paleopathology 17: 67-74.

Stevanovic, M. 1999. Report on Experimental Archaeology at Çatalhöyük. ÇATALHÖYÜK 1999 ARCHIVE REPORT http://www.C_atalhöyük.com/archive_reports/1999/ar99_20.html

Sussan TE et al (2014) Source of biomass cooking fuel determines pulmonary response to household air pollution. Am J Respir Cell Mol Biol 50:538-548. https://doi.org/10.1165/rcmb.2013-0201OC

Taşdemir, Y., Cindoruk, SS. and Esen, F. 2005 Monitoring of criteria air pollutants in Bursa, Turkey Env Monit Assess 110: 227-41

Wood, J.W., Milner, G.R., Harpending, H.C. and Weiss, K.M. 1992 The osteological paradox: problems of inferring prehistoric health from skeletal samples. Current Anthropology 33: 343-370.

Xiao, Q., Saikawa, E., Yokelson, R., Chen, P., Li, C. and Kang, S. (2015). Indoor air pollution from burning yak dung as a household fuel in Tibet. Atmospheric Environment, 102, pp.406-412.

Vandemergel X, Blocklet D, Decaux G. Periostitis and hypertrophic osteoarthropathy: etiologies and bone scan patterns in 115 cases. Eur J Intern Med. 2004;15(6):375-380.

West, SG. 2012. Systemic Diseases in Which Arthritis is a Feature, in Editor(s): Lee Goldman, Andrew I. Schafer (eds) Goldman's Cecil Medicine (Twenty Fourth Edition),W.B. Saunders, Pages 1747-1752 https://doi.org/10.1016/B978-1-4377-1604-7.00283-9 
Table 3: Test 1 values recorded for 10 minutes. Tests 2-5 values calculated for time period of $* *$ hours.

\begin{tabular}{|c|c|c|c|c|c|c|c|c|c|c|c|c|c|c|c|}
\hline \multirow{2}{*}{$\begin{array}{l}\text { Test } \\
\text { AQM }\end{array}$} & \multicolumn{3}{|c|}{ Test 1} & \multicolumn{3}{|l|}{ Test 2} & \multicolumn{3}{|l|}{ Test 3} & \multicolumn{3}{|l|}{ Test 4} & \multicolumn{3}{|l|}{ Test 5} \\
\hline & 1 & 2 & 3 & 1 & 2 & 3 & 1 & 2 & 3 & 1 & 2 & 3 & 1 & 2 & 3 \\
\hline Average & 112 & 69 & 62 & 13078 & 13447 & 60109 & 10402 & 12527 & 12793 & 13833 & 13827 & 45903 & 5192 & 5764 & 7689 \\
\hline $\mathrm{sd}$ & 187 & 37 & 44 & 8006 & 8023 & 63352 & 5965 & 6999 & 7943 & 4442 & 3761 & 44887 & 5007 & 5395 & 7938 \\
\hline $\max$ & 585 & 112 & 185 & 19771 & 19914 & 150000 & 18351 & 20000 & 25300 & 19540 & 19070 & 149000 & 19733 & 18115 & 36900 \\
\hline $\min$ & 16 & 26 & 38 & 8 & 22 & 28 & 90 & 90 & 166 & 11 & 45 & 28 & 21 & 34 & 23 \\
\hline
\end{tabular}


